\title{
Marked anti-tumour activity of the combination of YMI 55, a novel survivin suppressant, and platinum-based drugs
}

\author{
T Iwasa', I Okamoto*,', K Takezawa', K Yamanaka', T Nakahara², A Kita' ${ }^{2}$ H Koutoku², M Sasamata', \\ E Hatashita', Y Yamada', K Kuwata', M Fukuoka ${ }^{3}$ and K Nakagawa' \\ 'Department of Medical Oncology, Kinki University School of Medicine, 377-2 Ohno-higashi, Osaka-Sayama, Osaka 589-85 I I, Japan; ' Institute of Drug \\ Discovery Research, Astellas Pharma Inc., 2 I Miyukigaoka, Tsukuba-shi, Ibaraki 305-8585, Japan; ${ }^{3}$ Department of Medical Oncology, Kinki University \\ School of Medicine, Sakai Hospital, 2-7-I Harayamadai, Minami-ku Sakai, Osaka 590-0 I 32, Japan
}

\begin{abstract}
BACKGROUND: Survivin, a member of the inhibitor of apoptosis protein family, is an attractive target for cancer therapy. We have now investigated the effects of the combination of YMI55, a novel small-molecule inhibitor of survivin expression, and platinum compounds (cisplatin and carboplatin) on human non-small cell lung cancer (NSCLC) cell lines.

METHODS: The anti-cancer efficacy of YMI55 in combination with platinum compounds was evaluated on the basis of cell death and progression of tumour xenografts. Platinum compound-induced DNA damage was evaluated by immunofluorescence analysis of histone $\gamma$-H2AX.

RESULTS: Immunofluorescence analysis of histone $\gamma$-H2AX showed that YMI 55 delayed the repair of double-strand breaks induced in nuclear DNA by platinum compounds. The combination of YMI 55 and platinum compounds also induced synergistic increases both in the number of apoptotic cells and in the activity of caspase-3. Finally, combination therapy with YMI 55 and platinum compounds delayed the growth of NSCLC tumour xenografts in nude mice to an extent greater than that apparent with either treatment modality alone.

CONCLUSION: These results suggest that YMI55 sensitises tumour cells to platinum compounds both in vitro and in vivo, and that this effect is likely attributable to the inhibition of DNA repair and consequent enhancement of apoptosis.

British Journal of Cancer (2010) I 03, 36-42. doi:I0.1038/sj.bjc.66057I3 www.bjcancer.com
\end{abstract}

Published online I June 2010

(C) 2010 Cancer Research UK

Keywords: survivin; YMI55; apoptosis; DNA repair; non-small cell lung cancer

Survivin is a $16.5-\mathrm{kDa}$ member of the inhibitor of apoptosis protein (IAP) family and blocks the mitochondrial pathway of apoptosis by inhibiting caspases (Altieri, 2003a, b). Survivin also regulates cell division through interaction with the proteins INCENP and Aurora B (Wheatley et al, 2001). It is abundant in many types of cancer cells but not in the corresponding normal cells (Ambrosini et al, 1997; Marusawa et al, 2003; Altieri, 2004). High levels of survivin expression in cancer cells are associated with poor patient prognosis and survival, as well as with resistance to therapy and an increased rate of cancer recurrence (Monzo et al, 1999; Altieri, 2001; Rodel et al, 2005). Survivin has therefore become a therapeutic target and potentially important prognostic marker for many tumour types including non-small cell lung cancer (NSCLC) (Adida et al, 1998; Monzo et al, 1999). Reflecting the many mechanisms that seem to regulate survivin expression, diverse approaches have been evaluated for targeting survivin in experimental models ( $\mathrm{Li}$ et al, 1999; Olie et al, 2000; Grossman et al, 2001).

YM155, a small imidazolium-based compound, was identified by high-throughput screening of chemical libraries for inhibitors

*Correspondence: Dr I Okamoto;

E-mail: chi-okamoto@dotd.med.kindai.ac.jp

Revised 4 May 20 I0; accepted 6 May 20 I0; published online I June 2010 of the activity of the survivin gene promoter in a reporter assay (Nakahara et al, 2007). This compound specifically inhibits the expression of survivin at both the mRNA and protein levels and exhibits pronounced anti-cancer activity in pre-clinical models (Nakahara et al, 2007). An advantage of YM155 compared with previously investigated suppressors of survivin expression is that it is active in the subnanomolar range (Carter et al, 2001; Milella et al, 2001; O'Connor et al, 2002; De Schepper et al, 2003; Wall et al, 2003; Sah et al, 2006). Our previous pharmacokinetics analysis also revealed that YM155 becomes highly distributed to tumour tissue in tumour xenograft models in vivo (Nakahara et al, 2007). In addition, continuous YM155 infusion in mice did not result in systemic toxicity such as body weight loss or decreased blood cell count (Nakahara et al, 2007). Furthermore, we have recently shown that YM155 sensitised NSCLC cells to radiation both in vitro and in vivo, and that this effect of YM155 was likely attributable to the inhibition of DNA repair and enhancement of apoptosis that result from downregulation of survivin expression (Iwasa et al, 2008). YM155 is thus an attractive candidate drug for cancer therapy.

Despite its demonstrated efficacy in targeting tumour cells, the effects of YM155 in combination with DNA-damaging drugs have remained largely unknown. We have now examined the effects of the combination of YM155 and platinum compounds on human NSCLC cell lines both in vitro and in vivo. 


\section{MATERIALS AND METHODS}

\section{Cell culture and reagents}

The human NSCLC cell lines NCI-H460 (H460), Calu6, NCI-H358 (H358), and PC14 were obtained from the American Type Culture Collection (Manassas, VA, USA). The cells were cultured under an atmosphere of $5 \% \mathrm{CO}_{2}$ at $37^{\circ} \mathrm{C}$ in RPMI 1640 medium (Sigma, St Louis, MO, USA) supplemented with $10 \%$ foetal bovine serum. Cisplatin (CDDP) was obtained from Nippon Kayaku (Tokyo, Japan), and carboplatin (CBDCA) was from Bristol-Myers Squibb (New York, NY, USA). YM155 (Astellas Pharma Inc, Tokyo, Japan) was dissolved in dimethyl sulfoxide (DMSO).

\section{Immunoblot analysis}

Cells were washed twice with ice-cold phosphate-buffered saline (PBS) and then lysed in a solution containing $20 \mathrm{~mm}$ Tris $-\mathrm{HCl}$ ( $\mathrm{pH} 7.5$ ), $150 \mathrm{~mm} \mathrm{NaCl}, 1 \mathrm{~mm}$ EDTA, $1 \%$ Triton X-100, $2.5 \mathrm{~mm}$ sodium pyrophosphate, $1 \mathrm{~mm}$ phenylmethylsulfonyl fluoride, and leupeptin $\left(1 \mu \mathrm{g} \mathrm{ml}^{-1}\right)$. The protein concentration of lysates was determined with the Bradford reagent (Bio-Rad, Hercules, CA, USA), and equal amounts of protein were subjected to SDS polyacrylamide gel electrophoresis on a $15 \%$ gel. The separated proteins were transferred to a nitrocellulose membrane, which was then exposed to $5 \%$ non-fat dried milk in PBS for $1 \mathrm{~h}$ at room temperature before overnight incubation at $4{ }^{\circ} \mathrm{C}$ with rabbit polyclonal antibodies to human survivin ( $1: 1000$ dilution; R\&D Systems, Wiesbaden, Germany), to human c-IAP1 (1:1000 dilution; MBL International, Woburn, MA, USA), or to human XIAP (1:1000 dilution; Cell Signaling, Beverly, MA). The membrane was then washed with PBS containing $0.05 \%$ Tween 20 before incubation for $1 \mathrm{~h}$ at room temperature with horseradish peroxidase-conjugated goat antibodies to rabbit immunoglobulin G (Sigma). Immune complexes were finally detected with chemiluminescence reagents (PerkinElmer Life Science, Boston, MA, USA).

\section{Detection of apoptotic cells}

Cells were fixed with $4 \%$ paraformaldehyde for $1 \mathrm{~h}$ at room temperature, after which a minimum of 1000 cells per sample was evaluated for apoptosis with the use of the terminal deoxynucleotidyl transferase-mediated dUTP nick-end labelling (TUNEL) technique (In situ Cell Death Detection Kit; Boehringer Mannheim, Mannheim, Germany).

\section{Assay of caspase-3 activity}

The activity of caspase- 3 in cell lysates was measured with a CCP32/caspase-3 Fluometric Protease Assay Kit (MBL). Fluorescence attributable to cleavage of the DEVD-AFC substrate was measured at excitation and emission wavelengths of 390 and $460 \mathrm{~nm}$, respectively.

\section{Immunofluorescence staining of $\gamma$-H2AX}

Cells were grown to $50 \%$ confluence in two-well Lab-Tec Chamber Slides (Nunc, Naperville, IL, USA) and then cultured for $48 \mathrm{~h}$ in the presence of $50 \mathrm{nM}$ YM155 or vehicle (final DMSO concentration of $0.1 \%$; we confirmed that this DMSO concentration did not affect the proliferation of NSCLC cell lines) before additional exposure to $10 \mu \mathrm{M}$ CDDP or CBDCA. At various times thereafter, the cells were fixed with $4 \%$ paraformaldehyde for $10 \mathrm{~min}$ at room temperature, permeabilised with $0.1 \%$ Triton $\mathrm{X}-100$ for $10 \mathrm{~min}$ at $4^{\circ} \mathrm{C}$, and exposed to $5 \%$ non-fat dried milk for $10 \mathrm{~min}$ at room temperature. The slides were washed with PBS and then incubated at room temperature first for $2 \mathrm{~h}$ with mouse monoclonal antibodies to histone $\gamma$-H2AX (Upstate Biotechnology, Lake Placid, NY, USA) at a dilution of $1: 300$ and then for $1 \mathrm{~h}$ with Alexa Fluor 488-labeled goat antibodies to mouse immunoglobulin G (Molecular Probes, Eugene, OR, USA) at a dilution of $1: 700$. The slides were mounted in fluorescence mounting medium (Dako Cytomation, Hamburg, Germany), and fluorescence signals were visualised with a confocal laser-scanning microscope (Axiovert 200M; Carl Zeiss, Oberkochen, Germany) equipped with the LSM5 PASCAL system (Carl Zeiss). Three random fields each containing at least 50 cells were examined at a magnification of $\times 100$. Nuclei containing $\geqslant 10$ immunoreactive foci were counted as positive for $\gamma$-H2AX, and the percentage of positive cells was calculated (De Schepper et al, 2003).

\section{Evaluation of tumour growth in vivo}

Male nude (BALB/cAnNCrj-nu/nu) mice (5 weeks old) were obtained from Charles River Japan (Kanagawa, Japan). All animal studies were performed in accordance with the Recommendations for Handling of Laboratory Animals for Biomedical Research compiled by the Committee on Safety and Ethical Handling Regulations for Laboratory Animal Experiments, Kyoto University. The ethical procedures followed met the requirements of the UKCCCR guidelines (1998). Tumour cells $\left(2 \times 10^{6}\right)$ were implanted into the right hind leg of 6-week-old male athymic nude mice. Tumour volume was determined from caliper measurement of tumour length $(L)$ and width $(W)$ according to the formula $L W^{2} / 2$. Treatment was initiated when tumours in each group of animals achieved an average volume of $100-200 \mathrm{~mm}^{3}$. Treatment groups (each containing eight mice) consisted of vehicle control $(0.1 \%$ DMSO in physiological saline), YM155 alone, vehicle plus CDDP or CBDCA, and YM155 plus CDDP or CBDCA. Vehicle or YM155 at a dose of $5 \mathrm{mg}$ per $\mathrm{kg}$ of body mass was administered over seven consecutive days (days $0-6$ ) with the use of an implanted microosmotic pump (Alzet model 1007D; Durect, Cupertino, CA, USA). CDDP $\left(3 \mathrm{mg} \mathrm{kg}^{-1}\right)$ or CBDCA $\left(60 \mathrm{mg} \mathrm{kg}^{-1}\right)$ was administered intravenously on each of days $0-3$ and days 7-11, respectively.

\section{Statistical analysis}

Data are presented as means \pm s.e. and were compared between groups with the unpaired Student's $t$-test. A $P$-value of $<0.05$ was considered statistically significant.

\section{RESULTS}

\section{Specific inhibition of survivin expression in NSCLC cells by YM155}

We first examined the effect of YM155 on survivin expression in human NSCLC cell lines by immunoblot analysis. Exposure of H460, Calu6, H358, or PC14 cells to YM155 at 10-100 nM for $48 \mathrm{~h}$ inhibited survivin expression in a concentration-dependent manner (Figure 1A). In contrast, exposure of these cell lines to YM155 at $50 \mathrm{nM}$ for $48 \mathrm{~h}$ did not affect the abundance of other members of the IAP family including XIAP and c-IAP1 (Figure 1B), indicating that YM155 specifically inhibits survivin expression in the NSCLC cell lines.

\section{Enhancement of DNA-damaging agent-induced apoptosis in NSCLC cells by YM155}

We next examined the effect of YM155 on DNA-damaging agentinduced apoptosis in H460, Calu6, H358, or PC14 cells with the use of the TUNEL assay. Combined treatment of each cell line with YM155 and either CDDP or CBDCA resulted in an increase in the number of apoptotic cells at 24 and $48 \mathrm{~h}$ that was greater than the sum of the increases induced by YM155 or by CDDP or CBDCA alone (Figure 2). To confirm the results of the TUNEL assay, we measured the activity of caspase- 3 in cell lysates. Again, combined 
A

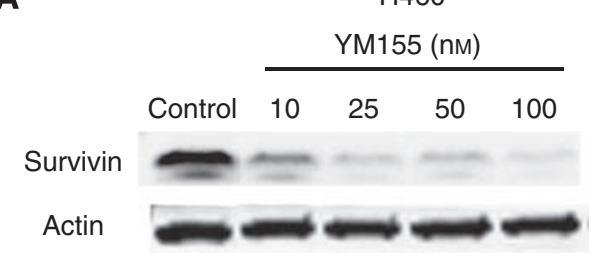

H358

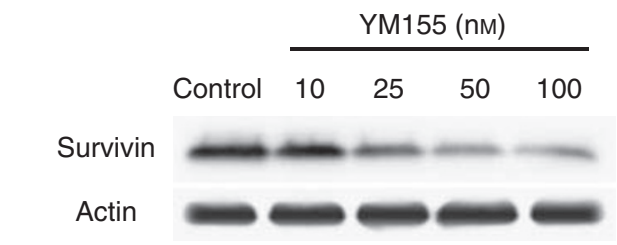

Calu6

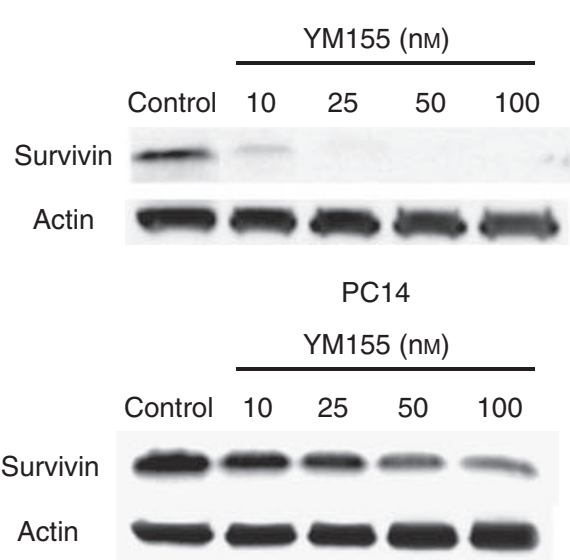

$\mathbf{B}$
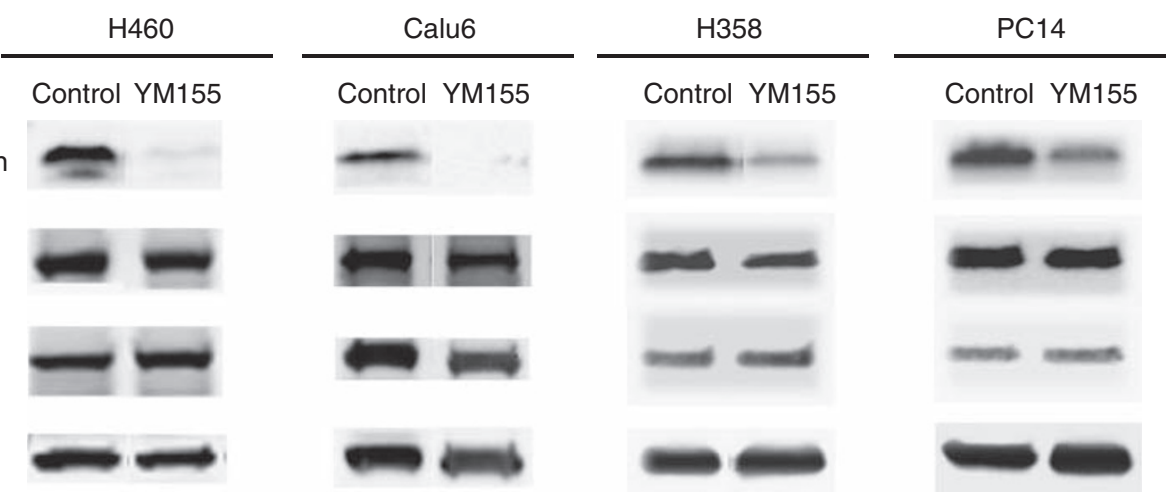

Figure I Effect of YMI55 on survivin expression in human non-small cell lung cancer (NSCLC) cells. (A) H460, Calu6, H358, or PCI4 cells were incubated in the absence (control, $0.1 \%$ dimethyl sulfoxide (DMSO)) or presence of the indicated concentrations of YMI 55 for $48 \mathrm{~h}$. Cell lysates were then prepared and subjected to immunoblot analysis with antibodies to survivin or to $\beta$-actin (loading control). (B) H460, Calu6, H358, or PCI4 cells were incubated in the absence or presence of 50 nM YMI55 for $48 \mathrm{~h}$, after which cell lysates were subjected to immunoblot analysis with antibodies to survivin, c-IAPI, XIAP, or $\beta$-actin.

treatment of H460, Calu6, H358, or PC14 cells with YM155 and either CDDP or CBDCA induced a synergistic increase in caspase-3 activity (Figure 2). These data thus suggested that YM155 promotes the induction of apoptosis by DNA-damaging agents in NSCLC cell lines.

\section{Effect of YM155 in combination with DNA-damaging agents on $\mathrm{H} 2 \mathrm{AX}$ phosphorylation}

We have previously shown that YM155 sensitises tumour cells to radiation by inhibiting the repair of radiation-induced DNA damage. CDDP and CBDCA are key drugs in NSCLC treatment and are known to induce DNA damage (Diggle et al, 2005). We therefore hypothesised that YM155 might inhibit the repair of CDDP- or CBDCA-induced DNA damage and thereby promote CDDP- or CBDCA-induced cell death. To explore this possibility, we determined whether YM155 might affect CDDP- or CBDCAinduced phosphorylation of histone $\mathrm{H} 2 \mathrm{AX}$ to yield $\gamma-\mathrm{H} 2 \mathrm{AX}$, which is a marker of DNA double-strand breaks (DSBs). Exposure of $\mathrm{H} 460$ or Calu6 cells to CDDP or CBDCA resulted in the gradual accumulation of $\gamma-\mathrm{H} 2 \mathrm{AX}$ foci, with this effect being maximal at $12 \mathrm{~h}$, after which the number of foci declined (Figure 3). Although YM155 did not affect the extent of CDDP- or CBDCA-induced focus formation, it significantly retarded the loss of foci normally apparent at $24 \mathrm{~h}$ after exposure to CDDP or CBDCA (Figure 3). These results thus suggested that downregulation of survivin expression by YM155 results in inhibition of the repair of DSBs induced by DNA-damaging agents in NSCLC cells.

\section{Enhancement of chemotherapy-induced tumour regression by YM155}

To determine whether the enhancement of the anti-tumour activity of DNA-damaging agents by YM155 observed in vitro might also be apparent in vivo, we injected Calu6 cells into nude mice to elicit the formation of solid tumours. After tumour formation, the mice were treated with YM155, CDDP, or both drugs. Combined treatment with CDDP and YM155 inhibited Calu6 tumour growth to a markedly greater extent than did treatment with either drug alone (Figure $4 \mathrm{~A}$ ). No pronounced tissue damage or toxicity such as weight loss (Figure 4A) was observed in mice in any of the four treatment groups.

Finally, we examined the effect of the combination of YM155 and CBDCA on tumour growth. Treatment with YM155 or CBDCA alone delayed tumour growth, whereas combined treatment inhibited tumour growth to a significantly greater extent (Figure 4B). Again, there was no evidence of toxicity on the basis of body weight loss (Figure $4 \mathrm{~B}$ ) and there were no animal deaths in any of the four groups. These data suggested that YM155 enhances the tumour response to platinum-based chemotherapy in vivo.

\section{DISCUSSION}

The success of anti-cancer therapies is often limited by the development of resistance to apoptosis, which may result from defects in common apoptotic pathways (Hanahan and Weinberg, 2000). In this context, approaches to counteract the action of 
survivin in tumour cells have been proposed with the dual aims of inhibiting tumour growth through promotion of spontaneous apoptosis and of enhancing the tumour cell response to apoptosisinducing agents (Altieri, 2003b). In this study, we found that the combination of YM155 and platinum compounds induced NSCLC cell apoptosis as well as the activation of caspase-3 to an extent greater than that apparent with either type of agent alone. Our findings thus suggest that YM155 acts in a synergistic manner to promote the induction of apoptosis by platinum compounds.

Cellular responses to stress or DNA damage are important for the maintenance of genomic stability and cellular integrity (Bunz et al, 1998; Hirao et al, 2000). Depending on its extent, cells either repair DNA damage or, when it is too severe for repair, initiate the cell death programme (Zhao et al, 2001). Agents that inhibit repair of DNA damage therefore increase the sensitivity of cells to ionising radiation and chemotherapeutic drugs (Banath et al, 2004; Taneja et al, 2004). The chemotherapeutic effect of platinum compounds results from their interaction with DNA; platinum thus induces the formation of DNA-protein crosslinks, DNA monoadducts, as well as interstrand or intrastrand DNA crosslinks (Chu, 1994; Siddik, 2003). These DNA adducts induce local distortion in the DNA double helix that results in strand unwinding and kinking (Chu, 1994). Survivin was previously shown to enhance tumour cell survival after radiation exposure through regulation of DSB repair (Chakravarti et al, 2004). We have previously shown that YM155 inhibited the repair of radiation-induced DSBs in NSCLC cells and that this effect likely accounted for the observed radiosensitising action of YM155 (Iwasa et al, 2008). We therefore investigated the effect of YM155 on the repair of platinum compound-induced DSBs by immunofluorescence imaging of $\gamma$-H2AX foci. Given that $\gamma$-H2AX appears rapidly at DNA DSBs and disappears as repair proceeds (Rogakou et al, 1998; Zhou and Elledge, 2000; Khanna et al, 2001; Shiloh and Kastan, 2001), it serves as a sensitive and specific marker for unrepaired DNA damage. We found that YM155 inhibited the repair of platinum compound-induced DSBs in NSCLC cells. Overexpression of survivin was previously shown to enhance DSB repair in tumour cells through upregulation of $\mathrm{Ku}$ protein (Jiang et al, 2009). Although it remains unclear whether YM155 affects Ku protein kinetics, our data suggest that the observed chemosensitisation by YM155 is attributable to inhibition of the repair of DNA damage induced by CDDP or CBDCA. Further investigations will be required to determine the mechanism underlying the effect of YM155 on DNA repair.

In addition to the initially identified isoform, four splice variants of human survivin have been described: survivin- $2 \alpha$, survivin- $2 \beta$, survivin- $\delta$-Ex3, and survivin-3 $\beta$ (Mahotka et al, 1999, 2002; Badran et al, 2004; Caldas et al, 2005a). However, little is known of
A
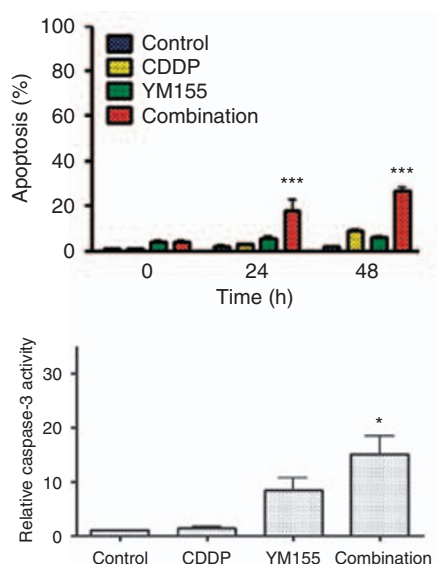

B
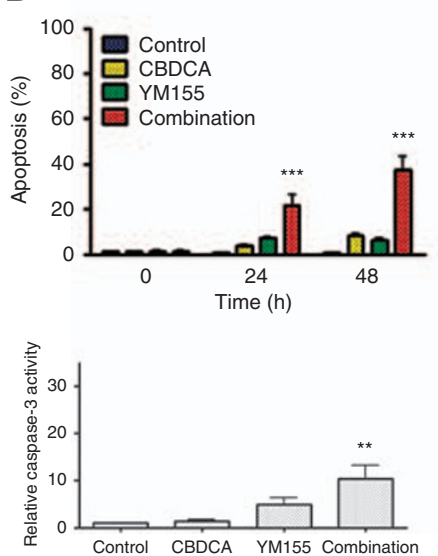

Calu6
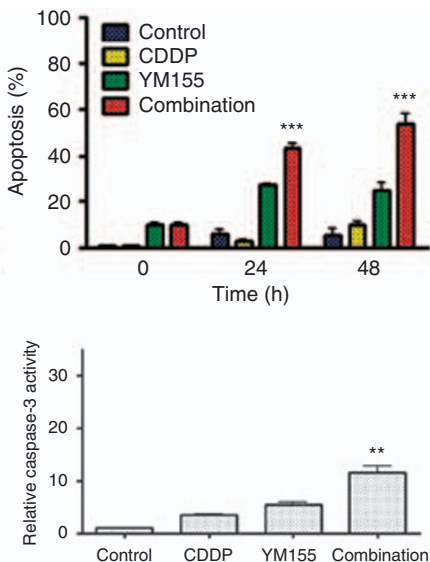

Calu6
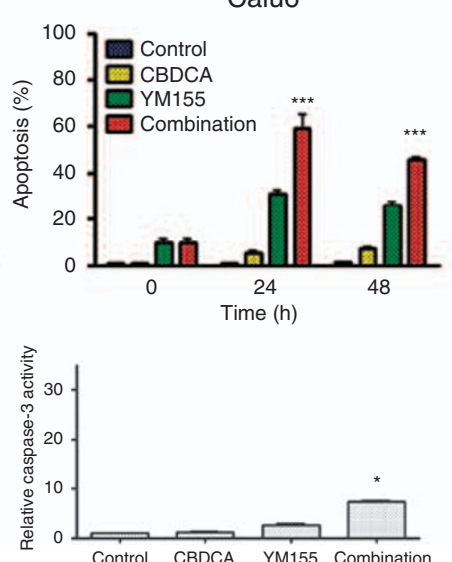

H358
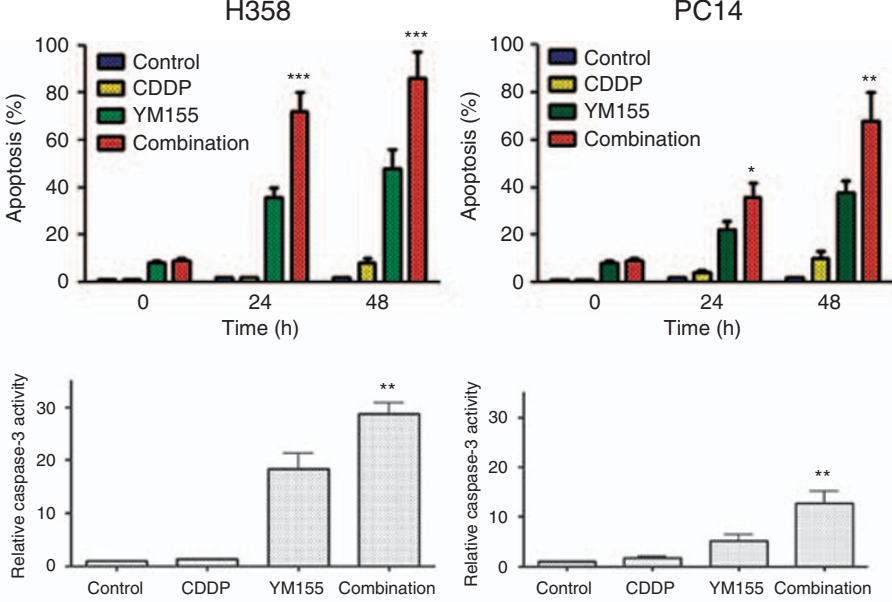

$\mathrm{H} 358$
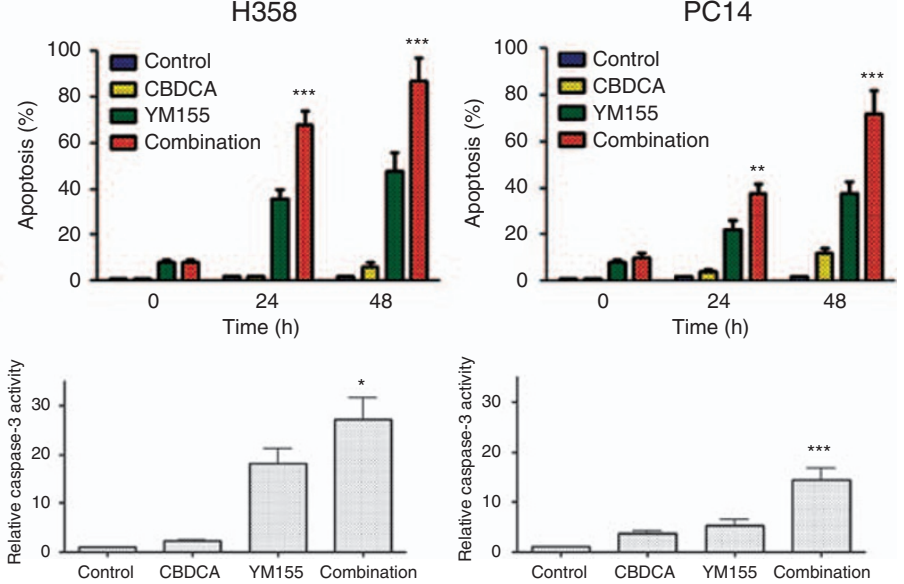

Figure 2 Effects of YMI55 on DNA-damaging agent-induced apoptosis and caspase-3 activity in H460, Calu6, H358, or PCI4 cells. Cells were incubated with $50 \mathrm{nM}$ YMI 55 or vehicle (0.1\% dimethyl sulfoxide (DMSO)) for $48 \mathrm{~h}$ and then for the indicated times (upper panels) or for $24 \mathrm{~h}$ (lower panels) in the additional absence or presence of $10 \mu \mathrm{M}$ CDDP $(\mathbf{A})$ or CBDCA $(\mathbf{B})$. The percentage of apoptotic cells was then determined by terminal deoxynucleotidyl transferase-mediated dUTP nick-end labeling (TUNEL) staining (upper panels), and cell lysates were assayed for caspase-3 activity (lower panels). All data are means \pm s.e. from three independent experiments; those for caspase- 3 activity are expressed relative to the corresponding value for the control condition. ${ }^{*} P<0.05$, * $P<0.00$ I, *** $P<0.000$ I vs the corresponding value for CDDP or CBDCA or for YMI55 alone. 
A

Control

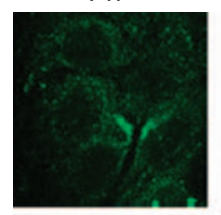

CDDP

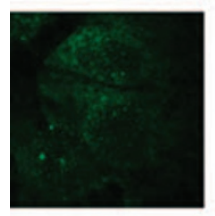

Combination

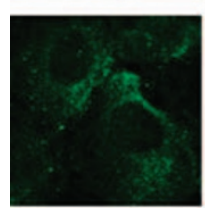

$1 \mathrm{~h}$

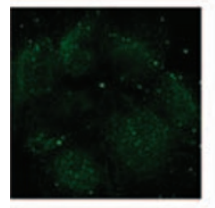

CBDCA

Combination
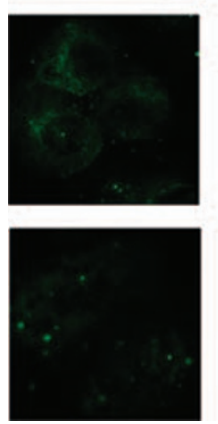

B
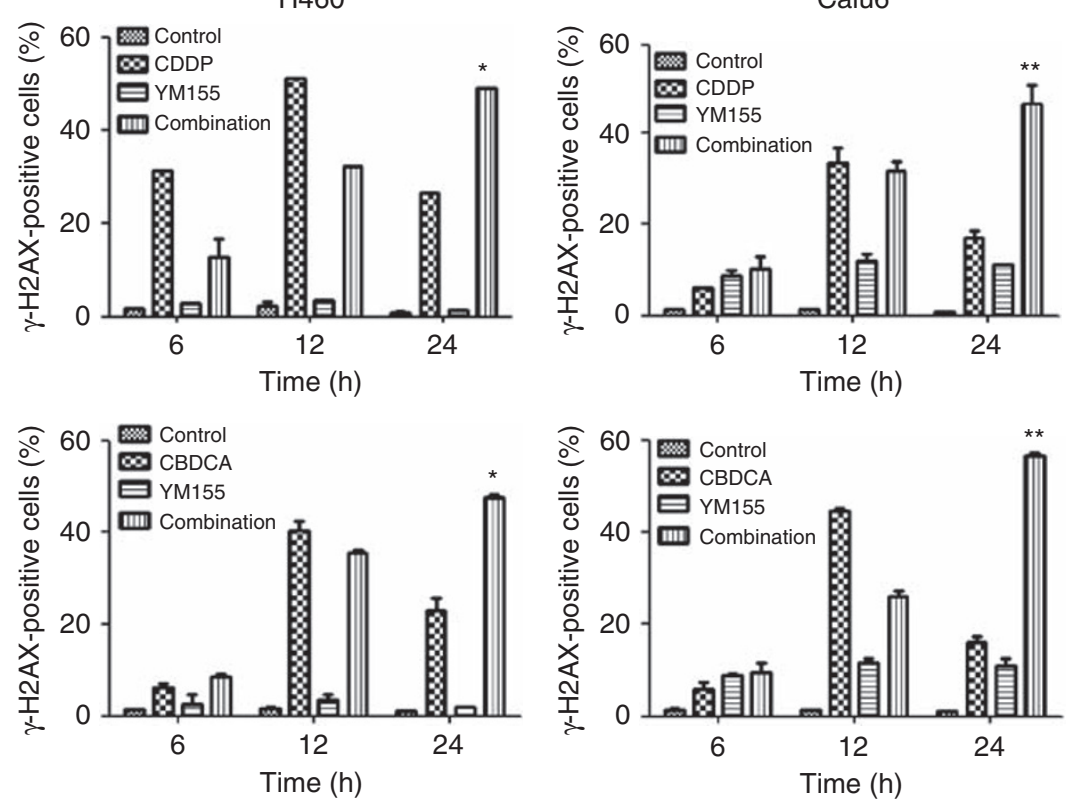
the differential functions of these alternative splice forms of survivin (Krieg et al, 2002; Mahotka et al, 2002; Caldas et al, 2005b; Noton et al, 2006). Given that the suppression of survivin expression by YM155 is mediated through inhibition of the transcriptional activity of the survivin gene promoter (Nakahara et al, 2007), it is possible that YM155 also inhibits the expression of these survivin variants.

No serious adverse haematological events related to drug treatment were reported in phase I studies of YM155 in singleagent therapy (Tolcher et al, 2008; Satoh et al, 2009). A recent phase II study showed that YM155 monotherapy is safe but only moderately effective (objective tumour response rate, 5.4\%) in patients with advanced NSCLC (Giaccone et al, 2009). Given this limited efficacy of YM155 as a single agent in NSCLC patients, the combination of YM155 with other agents may be beneficial. Platinum-based combination chemotherapy is the standard of care for most individuals with advanced NSCLC (Chu, 1994). We have shown that treatment of NSCLC cells with YM155 results in a marked increase in the anti-tumour effects of CDDP and CBDCA both in vitro and in vivo, suggesting that the combination of YM155 and platinum compounds may have potential as a novel therapeutic regimen. Clinical studies of YM155 in combination with platinum-based chemotherapy are thus warranted.
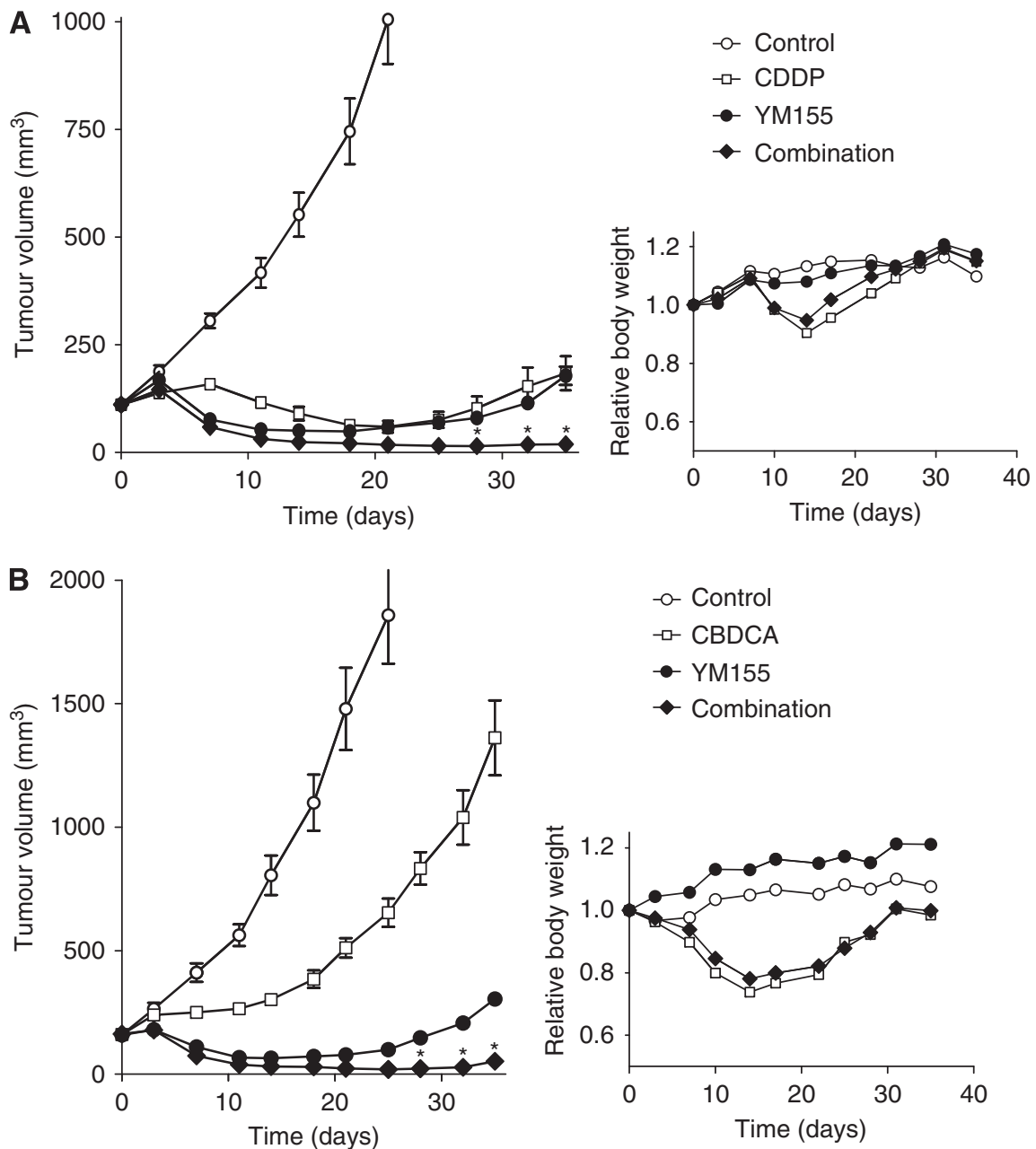

$$
\begin{aligned}
& - \text { - Control } \\
& - \text { - CBDCA } \\
& - \text { YM155 } \\
& \bullet \text { Combination }
\end{aligned}
$$

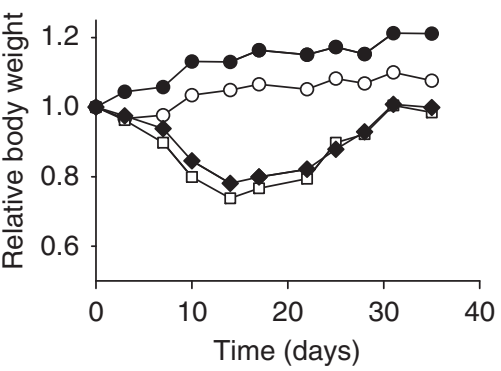

Figure 4 Effects of YMI55 on the anti-tumour action of CDDP or CBDCA in vivo. Calu6 cells were injected into the right hind limb of nude mice and allowed to form tumours, after which the mice were assigned to one of four treatment groups (control, CDDP (A) or CBDCA (B) alone, YMI55 alone, or the combination of YMI 55 and either $\operatorname{CDDP}(\mathbf{A})$ or CBDCA $(\mathbf{B})$ ) as described in Materials and Methods. Tumour volume was measured at the indicated times after the onset of treatment (left panels); values for mice in the control group are not shown for later time points to highlight differences among the other three groups. Body weight was also measured in each treatment group at the indicated times and is expressed relative to the corresponding value for time 0 (right panels). All data are means \pm s.e. from eight mice per group. $* P<0.000$ I vs the corresponding value for treatment with CDDP $(\mathbf{A})$ or $C B D C A$ (B) alone or with YMI55 alone.

Figure 3 Effect of YMI55 on the formation of $\gamma$-H2AX foci induced by DNA-damaging agents in non-small cell lung cancer (NSCLC) cells. (A) H460 cells were incubated with vehicle (0.1\% dimethyl sulfoxide (DMSO)) or $50 \mathrm{nM}$ YMI55 for $48 \mathrm{~h}$ and then for the indicated times in the additional absence or presence of $10 \mu \mathrm{M}$ CDDP or CBDCA. The cells were then fixed and subjected to immunofluorescence staining for $\gamma$-H2AX (green fluorescence). (B) $\mathrm{H} 460$ or Calu6 cells were incubated with vehicle or $50 \mathrm{nM}$ YMI55 for $48 \mathrm{~h}$ and then for the indicated times in the additional absence or presence of $10 \mu \mathrm{M}$ CDDP or CBDCA. They were then fixed and subjected to immunofluorescence staining for $\gamma$-H2AX, and the percentage of cells containing $\gamma-\mathrm{H} 2 \mathrm{AX}$ foci was determined. Data are means \pm s.e. from three independent experiments. $* P<0.05$, $* * P<0.00 \mathrm{I} v \mathrm{~s}$ the corresponding value for CDDP or CBDCA alone. 


\section{REFERENCES}

Adida C, Berrebi D, Peuchmaur M, Reyes-Mugica M, Altieri DC (1998) Anti-apoptosis gene, survivin, and prognosis of neuroblastoma. Lancet 351: $882-883$

Altieri DC (2001) The molecular basis and potential role of survivin in cancer diagnosis and therapy. Trends Mol Med 7: 542-547

Altieri DC (2003a) Survivin and apoptosis control. Adv Cancer Res 88: 31 - 52 Altieri DC (2003b) Validating survivin as a cancer therapeutic target. Nat Rev Cancer 3: $46-54$

Altieri DC (2004) Molecular circuits of apoptosis regulation and cell division control: the survivin paradigm. J Cell Biochem 92: 656-663

Ambrosini G, Adida C, Altieri DC (1997) A novel anti-apoptosis gene, survivin, expressed in cancer and lymphoma. Nat Med 3: 917-921

Badran A, Yoshida A, Ishikawa K, Goi T, Yamaguchi A, Ueda T, Inuzuka M (2004) Identification of a novel splice variant of the human anti-apoptopsis gene survivin. Biochem Biophys Res Commun 314: $902-907$

Banath JP, Macphail SH, Olive PL (2004) Radiation sensitivity, H2AX phosphorylation, and kinetics of repair of DNA strand breaks in irradiated cervical cancer cell lines. Cancer Res 64: 7144-7149

Bunz F, Dutriaux A, Lengauer C, Waldman T, Zhou S, Brown JP, Sedivy JM, Kinzler KW, Vogelstein B (1998) Requirement for p53 and p21 to sustain G2 arrest after DNA damage. Science 282: 1497 - 1501

Caldas H, Honsey LE, Altura RA (2005a) Survivin 2alpha: a novel Survivin splice variant expressed in human malignancies. Mol Cancer 4: 11

Caldas H, Jiang Y, Holloway MP, Fangusaro J, Mahotka C, Conway EM, Altura RA (2005b) Survivin splice variants regulate the balance between proliferation and cell death. Oncogene 24: 1994-2007

Carter BZ, Milella M, Altieri DC, Andreeff M (2001) Cytokine-regulated expression of survivin in myeloid leukemia. Blood 97: 2784-2790

Chakravarti A, Zhai GG, Zhang M, Malhotra R, Latham DE, Delaney MA, Robe P, Nestler U, Song Q, Loeffler J (2004) Survivin enhances radiation resistance in primary human glioblastoma cells via caspase-independent mechanisms. Oncogene 23: $7494-7506$

Chu G (1994) Cellular responses to cisplatin. The roles of DNA-binding proteins and DNA repair. J Biol Chem 269: 787-790

De Schepper S, Bruwiere H, Verhulst T, Steller U, Andries L, Wouters W, Janicot M, Arts J, Van Heusden J (2003) Inhibition of histone deacetylases by chlamydocin induces apoptosis and proteasomemediated degradation of survivin. J Pharmacol Exp Ther 304: $881-888$

Diggle CP, Bentley J, Knowles MA, Kiltie AE (2005) Inhibition of doublestrand break non-homologous end-joining by cisplatin adducts in human cell extracts. Nucleic Acids Res 33: 2531-2539

Giaccone G, Zatloukal P, Roubec J, Floor K, Musil J, Kuta M, van Klaveren RJ, Chaudhary S, Gunther A, Shamsili S (2009) Multicenter phase II trial of YM155, a small-molecule suppressor of survivin, in patients with advanced, refractory, non-small-cell lung cancer. J Clin Oncol 27: 4481 - 4486

Grossman D, Kim PJ, Schechner JS, Altieri DC (2001) Inhibition of melanoma tumor growth in vivo by survivin targeting. Proc Natl Acad Sci USA 98: $635-640$

Hanahan D, Weinberg RA (2000) The hallmarks of cancer. Cell 100: $57-70$

Hirao A, Kong YY, Matsuoka S, Wakeham A, Ruland J, Yoshida H, Liu D Elledge SJ, Mak TW (2000) DNA damage-induced activation of p53 by the checkpoint kinase Chk2. Science 287: 1824-1827

Iwasa T, Okamoto I, Suzuki M, Nakahara T, Yamanaka K, Hatashita E, Yamada Y, Fukuoka M, Ono K, Nakagawa K (2008) Radiosensitizing effect of YM155, a novel small-molecule survivin suppressant, in nonsmall cell lung cancer cell lines. Clin Cancer Res 14: 6496-6504

Jiang G, Ren B, Xu L, Song S, Zhu C, Ye F (2009) Survivin may enhance DNA double-strand break repair capability by up-regulating Ku70 in human KB cells. Anticancer Res 29: 223-228

Khanna KK, Lavin MF, Jackson SP, Mulhern TD (2001) ATM, a central controller of cellular responses to DNA damage. Cell Death Differ 8: $1052-1065$

Krieg A, Mahotka C, Krieg T, Grabsch H, Muller W, Takeno S, Suschek CV, Heydthausen M, Gabbert HE, Gerharz CD (2002) Expression of different survivin variants in gastric carcinomas: first clues to a role of survivin-2B in tumour progression. $\mathrm{Br}$ J Cancer 86: 737-743

Li F, Ackermann EJ, Bennett CF, Rothermel AL, Plescia J, Tognin S, Villa A, Marchisio PC, Altieri DC (1999) Pleiotropic cell-division defects and apoptosis induced by interference with survivin function. Nat Cell Biol 1: $461-466$
Mahotka C, Liebmann J, Wenzel M, Suschek CV, Schmitt M, Gabbert HE Gerharz CD (2002) Differential subcellular localization of functionally divergent survivin splice variants. Cell Death Differ 9: 1334-1342

Mahotka C, Wenzel M, Springer E, Gabbert HE, Gerharz CD (1999) Survivin-deltaEx3 and survivin-2B: two novel splice variants of the apoptosis inhibitor survivin with different antiapoptotic properties. Cancer Res 59: 6097-6102

Marusawa H, Matsuzawa S, Welsh K, Zou H, Armstrong R, Tamm I, Reed JC (2003) HBXIP functions as a cofactor of survivin in apoptosis suppression. EMBO J 22: $2729-2740$

Milella M, Kornblau SM, Estrov Z, Carter BZ, Lapillonne H, Harris D, Konopleva M, Zhao S, Estey E, Andreeff M (2001) Therapeutic targeting of the MEK/MAPK signal transduction module in acute myeloid leukemia. J Clin Invest 108: $851-859$

Monzo M, Rosell R, Felip E, Astudillo J, Sanchez JJ, Maestre J, Martin C, Font A, Barnadas A, Abad A (1999) A novel anti-apoptosis gene: re-expression of survivin messenger RNA as a prognosis marker in non-small-cell lung cancers. J Clin Oncol 17: 2100-2104

Nakahara T, Takeuchi M, Kinoyama I, Minematsu T, Shirasuna K, Matsuhisa A, Kita A, Tominaga F, Yamanaka K, Kudoh M, Sasamata M (2007) YM155, a novel small-molecule survivin suppressant, induces regression of established human hormone-refractory prostate tumor xenografts. Cancer Res 67: 8014-8021

Noton EA, Colnaghi R, Tate S, Starck C, Carvalho A, Ko Ferrigno P, Wheatley SP (2006) Molecular analysis of survivin isoforms: evidence that alternatively spliced variants do not play a role in mitosis. $J$ Biol Chem 281: $1286-1295$

O'Connor DS, Wall NR, Porter AC, Altieri DC (2002) A p34(cdc2) survival checkpoint in cancer. Cancer Cell 2: $43-54$

Olie RA, Simoes-Wust AP, Baumann B, Leech SH, Fabbro D, Stahel RA, Zangemeister-Wittke U (2000) A novel antisense oligonucleotide targeting survivin expression induces apoptosis and sensitizes lung cancer cells to chemotherapy. Cancer Res 60: 2805-2809

Rodel F, Hoffmann J, Distel L, Herrmann M, Noisternig T, Papadopoulos T, Sauer R, Rodel C (2005) Survivin as a radioresistance factor, and prognostic and therapeutic target for radiotherapy in rectal cancer. Cancer Res 65: $4881-4887$

Rogakou EP, Pilch DR, Orr AH, Ivanova VS, Bonner WM (1998) DNA double-stranded breaks induce histone $\mathrm{H} 2 \mathrm{AX}$ phosphorylation on serine 139. J Biol Chem 273: $5858-5868$

Sah NK, Munshi A, Hobbs M, Carter BZ, Andreeff M, Meyn RE (2006) Effect of downregulation of survivin expression on radiosensitivity of human epidermoid carcinoma cells. Int J Radiat Oncol Biol Phys 66: $852-859$

Satoh T, Okamoto I, Miyazaki M, Morinaga R, Tsuya A, Hasegawa Y, Terashima M, Ueda S, Fukuoka M, Ariyoshi Y, Saito T, Masuda N, Watanabe H, Taguchi T, Kakihara T, Aoyama Y, Hashimoto Y, Nakagawa K (2009) Phase I study of YM155, a novel survivin suppressant, in patients with advanced solid tumors. Clin Cancer Res 15: 3872-3880

Shiloh Y, Kastan MB (2001) ATM: genome stability, neuronal development, and cancer cross paths. Adv Cancer Res 83: 209-254

Siddik ZH (2003) Cisplatin: mode of cytotoxic action and molecular basis of resistance. Oncogene 22: $7265-7279$

Taneja N, Davis M, Choy JS, Beckett MA, Singh R, Kron SJ, Weichselbaum RR (2004) Histone H2AX phosphorylation as a predictor of radiosensitivity and target for radiotherapy. J Biol Chem 279: 2273-2280

Tolcher AW, Mita A, Lewis LD, Garrett CR, Till E, Daud AI, Patnaik A, Papadopoulos K, Takimoto C, Bartels P, Keating A, Antonia S (2008) Phase I and pharmacokinetic study of YM155, a small-molecule inhibitor of survivin. J Clin Oncol 26: 5198-5203

Wall NR, O'Connor DS, Plescia J, Pommier Y, Altieri DC (2003) Suppression of survivin phosphorylation on Thr34 by flavopirido enhances tumor cell apoptosis. Cancer Res 63: 230-235

Wheatley SP, Carvalho A, Vagnarelli P, Earnshaw WC (2001) INCENP is required for proper targeting of survivin to the centromeres and the anaphase spindle during mitosis. Curr Biol 11: 886-890

Zhao H, Spitz MR, Tomlinson GE, Zhang H, Minna JD, Wu X (2001) Gamma-radiation-induced G2 delay, apoptosis, and p53 response as potential susceptibility markers for lung cancer. Cancer Res 61: 7819-7824

Zhou BB, Elledge SJ (2000) The DNA damage response: putting checkpoints in perspective. Nature 408: $433-439$ 